\title{
Nipah Virus Research: A Scientometric Assessment of Global Publications Output during 1999-2018
}

\author{
B. M. Gupta ${ }^{1}$, K K Mueen Ahmed ${ }^{2}$, Ritu Gupta ${ }^{3 *}$
}

\section{B. M. Gupta', K K Mueen Ahmed $^{2}$, Ritu Gupta ${ }^{3 *}$}

\author{
${ }^{1} 1173$ Sector 15, Panchkula 134 113, \\ Haryana, INDIA. \\ ${ }^{2}$ Phcog.Net and SciBiolMed.Org, \\ Bengaluru, Karnataka, INDIA. \\ ${ }^{3} 1$ KJA Arjun Nagar, Safdarjang Enclave, \\ New Delhi 110029, INDIA. \\ Correspondence \\ Ritu Gupta \\ 1K/A Arjun Nagar, Safdarjang Enclave, \\ New Delhi 110029, INDIA. \\ Email: ritu7648@gmail.com \\ History \\ - Submission Date: 10-04-2018 \\ - Revised Date: 22-06-2018 \\ - Accepted Date: 03-07-2018
}

DOI : 10.5530/ijmedph.2018.2.11

Article Available online

http://www.ijmedph.org/v8/i2

\section{Copyright}

(C) 2018 Phcog.Net. This is an openaccess article distributed under the terms of the Creative Commons Attribution 4.0 International license.

\begin{abstract}
The present study examined 1181 global publications in Nipah virus, as covered in multidisciplinary and bibliographic Scopus database during 1999-2018, with a view to understand their growth rate, global share, citation impact, international collaborative papers share, distribution of publications by broad subjects, productivity and citation profile of top organizations and authors, preferred media of communication and bibliographic characteristics of high cited papers. The global publications in Nipah virus registered an annual average growth rate of $16.23 \%$ and its citation impact averaged to 28.05 citations per paper. Among the 62 countries participating in global Nipah virus research, the top 10 more productive countries account together for more than $100 \%$ of its global research output and citation share. The individual global publication share of top 10 most productive countries varied widely $4.23 \%$ to $45.98 \%$ during $1999-2018$, with USA accounting for the highest publication share $(45.98 \%)$, followed by Australia (16.77\%), Malaysia (11.09\% share), and other 7 countries (from $4.23 \%$ to $7.96 \%$ ) during $1999-2018$. Four of top 10 countries scored relative citation index above the world average of 1.28: Malaysia (1.67), Australia (1.47), Bangladesh (1.41) and USA (1.37) during 1999-2018. The international collaborative papers share of top 10 most productive countries in Nipah virus research varied widely from $24.56 \%$ (India) to $88.46 \%$ (Bangladesh). Medicine, among various broad subjects, contributed the largest publications share of $59.97 \%$ to global Nipah virus research, followed by immunology and microbiology $(42.51 \%)$, biochemistry, genetics and molecular biology $(21.25 \%)$, agricultural and biological sciences $(11.85 \%)$, and other 3 sub-fields contribution varying from $4.57 \%$ to $6.10 \%$ during 1999-2018. Among various organizations and authors contributing to global Nipah virus research, the 15 most productive global organizations and authors together contributed $65.11 \%$ and $48.69 \%$ global publication share and $99.15 \%$ and $89.29 \%$ global citation share respectively during 1999-2018. Amongst 1077 journal papers (in 410 journals) in global Nipah virus research, the top 20 most productive journals contributed 40.39\% share of total journal publication output during 1999-2018. Seventy nine (79) publications were found to be high cited, as they registered citations from 101-793 during 1999-2018 and they together received 114880 citations, which averaged to 188.359 citations per paper.

Key words: Nipah virus, Virology, Infectious diseases, Global publications, Scientometrics, Bibliometrics.
\end{abstract}

\section{INTRODUCTION}

Nipah virus (NIPV) was first isolated from cerebrospinal fluid (CSF) specimens collected from encephalitic patients in Malaysia in 1999. Morphologic, serologic and genetic studies indicated that the virus was closely related to Hendra virus (HENV) isolated in 1994 in Australia and both viruses (non-segmented, negativestranded RNA viruses) form the new Henipavirus genus within the Paramyxoviridae family. ${ }^{1}$ Its name originated from Sungai Nipah, a village in the Malaysian Peninsula where pig farmers became ill with encephalitis. ${ }^{2}$

Nipah virus was first identified as a zoonotic pathogen after an outbreak involving severe respiratory illness in pigs and encephalitic disease in humans in Malaysia and Singapore in 1998 and 1999. Three years later, a genetically distinct $\mathrm{NiV}$ independently emerged in India as well as in Bangladesh, where human $\mathrm{NiV}$ outbreak events have been reported nearly every year since. A putative NiV also caused an outbreak of disease in horses and people in the Philippines in 2014. To date, there is no reported evidence of NiV outbreaks in humans emerging in any other country than Malaysia, Singapore, Bangladesh, India and Philippines. More than 600 cases of NiV human infections have been reported globally. A total of 276 cases were reported with 106 fatalities (38\%) in Malaysia, but case fatalities in later outbreaks in India and Bangladesh were associated with significantly higher case fatality rates of 43 to $100 \% .^{3}$ From 1998 to 2015 , more than 600 cases of Nipah virus human infections were reported. Subsequent outbreaks in India and Bangladesh have occurred with high case fatality. ${ }^{4}$

Cite this article : Gupta BM, Ahmed KKM, Gupta R. Nipah Virus Research: A Scientometric Assessment of Global Publications Output during 1999-2018. Int J Med Public Health. 2018;8(2):48-55. 
Gupta, et al.: Nipah Virus Research: A Scientometric Assessment

Virus transmission from bats to humans occurs through inhalation, contact or consumption of $\mathrm{NiV}$ contaminated foods. $\mathrm{NiV}$ is transmitted by zoonotic (from bats to humans, or from bats to pigs and then to humans) as well as human-to-human routes. Human-to-human transmission is particularly notable in the outbreaks in India and Bangladesh, where it has been reported to account for $75 \%$ and $51 \%$ of cases, respectively. At present no vaccines or antiviral drugs are available for $\mathrm{NiV}$ disease and the treatment is just supportive. Current prevention strategies focus on raising disease awareness in affected areas. ${ }^{3}$

Nipah virus can cause a range of mild to severe disease in domestic animals such as pigs. Nipah virus infection in humans causes a range of clinical presentations, from asymptomatic infection (subclinical) to acute respiratory infection and fatal encephalitis. Infected people initially develop influenza-like symptoms of fever, headaches, myalgia (muscle pain), vomiting and sore throat. This can be followed by dizziness, drowsiness, altered consciousness and neurological signs that indicate acute encephalitis. Some people can also experience atypical pneumonia and severe respiratory problems, including acute respiratory distress. Encephalitis and seizures occur in severe cases, progressing to coma within 24 to $48 \mathrm{~h}$. The case fatality rate is estimated at $40 \%$ to $75 \%$; however, this rate can vary by outbreak depending on local capabilities for epidemiological surveillance and clinical management. Nipah is believed to be transmitted from what are called flying foxes or mega bats, so called because they are the largest bat species. They eat fruits and live in trees. These are a part of the old-world fruit bat family called pteropid bats. Bats often end up being reservoirs for a number of severe infectious diseases including Ebola, SARS coronavirus, Nipah and Hendra. ${ }^{5}$

The persistence and circulation of the virus within the bat population (Pteropus spp.) and the wide geographical range of the potential reservoirs from Madagascar to Australia, have great implications on human and animal public health, prophylaxis and health education measures. ${ }^{4}$

\section{Literature Review}

So far only one bibliometric study on international contribution to Nipah virus research during 1999-2010 was conducted by Safahieh, Sanni and Zainab, ${ }^{6}$ which examined 462 papers on Nipah virus research, with a focus on identifying active authors, institutions, countries and citations received. Data was extracted from SCI-Expanded database, (Web of Science) and analyzed using descriptive figures and tables. The active contributing countries were USA (with $41.0 \%$ share), followed by Australia (19.3\%), Malaysia (16.0\%), England (6.5\%) and France (5.6\%). The productive authors are mainly affiliated to the Centre for Disease Control and Prevention, USA and Commonwealth Scientific and Industrial Research Organization (CSIRO) in Australia and University of Malaya Medical Centre, Malaysia.

\section{OBJECTIVES}

The present study examines the performance of global Nipah virus research during 1999-2018, based on publications output indexed in Scopus database. The study looks at the distribution of global publication output of the world and of 10 most productive countries, by document type and source type, growth rate of its annual and ten year output, the share of international collaborative publications of leading countries, broad subject-wise publication scatter across sub-fields, identification of significant keywords depicting trends in research, publication output and citation impact of top 15 global organizations and authors, identification of 20 significant journals and characteristics of its 79 high cited publications.

\section{MATERIALS AND METHODS}

The publication data on Nipah virus research for the present study was derived from the Scopus database (http://www.scopus.com) covering the period 1999-2018. Keyword "Nipah virus" was searched in "TITLEABS-KEY" tag during the period 1999-2018 to get global publication data. This search string was applied first for searching global publication data on Nipah virus research and then further restricted to individual country by name in "country tag" one by one to ascertain publication output of top 10 most productive countries (including India) in Nipah virus research. The first search string was subsequently refined, using analytical tags in Scopus database, by "subject area tag", "country tag", "source title tag", "journal title name" and "affiliation tag", to get data/ information on the distribution of publications output by subject, collaborating countries, author-wise, organization-wise and journal-wise, etc. For citation data, citations to publications were also collected from date of publication till 24 May 2018. The data for the study was collected on 24 May 2018. The data covered for 2018 was incomplete. A number of bibliometric indicators were used to measure the global performance of Nipah virus research.

\section{RESULTS}

The global research output of the world in field of Nipah virus cumulated to 1181 publications in 20 years during 1999-2018. The annual output of the world in Nipah virus research increased from 9 in the year 1999 to 57 in 2017 , registering $16.23 \%$ growth per annum. The research output in fact first increased from 9 to 106 in 2013 and the decreased to 57 in 2017. The cumulative world output in Nipah virus research in 10 years 1999-2008 increased from 458 to 723 publications during succeeding ten-year period $2009-18$, registering $57.86 \%$ growth. Of the total global publications output, $58.51 \%$ (691) appeared as articles, $22.86 \%$ (270) as reviews, $4.40 \%$ (52) as book chapters, $3.73 \%$ (44) as conference papers, $3.05 \%$ (36) as editorials, $2.79 \%(33)$ as notes, $1.95 \%(23)$ as short surveys, $1.69 \%(20)$ as letters, $0.42 \%$ (5 each) as books and erratum, $0.02 \%(1)$ and $0.17 \%(2)$ as conference reviews. The citation impact of global publications on Nipah virus research in 20 years averaged to 28.05 citations per publication (CPP) during 1999-2018; its ten-yearly impact averaged to 46.83 CPP for the period 1999-2008, which sharply declined to 16.15 CPP in the succeeding ten-years 2009-2018 (Table 1).

\section{Top 10 Most Productive Countries in Nipah Virus.}

The global research output in the field of Nipah Virus research had originated from 62 countries during 1999-2018, of which 46 published 1-10 papers each in 20 years, 7 countries 11-50 papers each, 6 countries 51-100 papers each, 2 countries 101-200 papers each and 1 county 1543 papers. The top 10 most productive countries in Nipah Virus have contributed 50 to 543 publications each during 1999-2018 (Table 2). The top 10 most productive countries in Nipah Virus research accounted for more than $100.0 \%$ (113.12\%) global publication share and more than $100.0 \%$ (148.58\%) citation share during 1999-2018. Their ten-early output accounted for more than $100.0 \%$ (104.15\%) global publication share during 1999-2008 which increased to more than $100.0 \%$ (118.81\%) during succeeding ten-year period 2009-18. Country-wise, the global publication share of top 10 countries varied widely $4.23 \%$ to $45.98 \%$ during 1999 2018, with USA accounting for the highest publication share (45.98\%), followed by Australia (16.77\%), Malaysia (11.09\% share) and other 7 countries (from $4.23 \%$ to $7.96 \%$ ) during 1999-2018. The global publication share registered a increasing publication share in USA $(8.77 \%)$, France (5.16\%), Bangladesh (3.63\%), India (2.89\%), Germany (1.64\%), Singapore (1.57\%), Canada (1.41\%) and U.K. (0.10\%), as against decrease in Malaysia (8.63\%) and Australia (1.86) in ten years period (1999-2008 and 2009-18). Four of top 10 countries scored relative citation index 


\begin{tabular}{|c|c|c|c|}
\hline \multirow[t]{2}{*}{ Publication Period } & \multicolumn{3}{|c|}{ World } \\
\hline & TP & TC & CPP \\
\hline 1999 & 9 & 925 & 102.78 \\
\hline 2000 & 33 & 2258 & 68.42 \\
\hline 2001 & 35 & 2534 & 72.40 \\
\hline 2002 & 38 & 1860 & 48.95 \\
\hline 2003 & 35 & 1925 & 55.00 \\
\hline 2004 & 65 & 3254 & 50.06 \\
\hline 2005 & 56 & 2226 & 39.75 \\
\hline 2006 & 61 & 2374 & 38.92 \\
\hline 2007 & 59 & 1707 & 28.93 \\
\hline 2008 & 67 & 2385 & 35.60 \\
\hline 2009 & 73 & 2280 & 31.23 \\
\hline 2010 & 75 & 2011 & 26.81 \\
\hline 2011 & 57 & 1283 & 22.51 \\
\hline 2012 & 90 & 2408 & 26.76 \\
\hline 2013 & 106 & 1745 & 16.46 \\
\hline 2014 & 80 & 974 & 12.18 \\
\hline 2015 & 88 & 538 & 6.11 \\
\hline 2016 & 78 & 365 & 4.68 \\
\hline 2017 & 57 & 71 & 1.25 \\
\hline 2018 & 19 & 4 & 0.21 \\
\hline 1999-2008 & 458 & 21448 & 46.83 \\
\hline $2009-18$ & 723 & 11679 & 16.15 \\
\hline $1999-2018$ & 1181 & 33127 & 28.05 \\
\hline
\end{tabular}

TP=Total Papers; TC=Total Citations; $\mathrm{CPP}=$ Citations Per Paper above the world average of 1.28: Malaysia (1.67), Australia

(1.47), Bangladesh (1.41) and USA (1.37) during 1999-2018.

\section{International Collaboration}

The international collaborative output of top 10 most productive countries in Nipah Virus research as a national share in the country-wise output varied widely from $24.56 \%$ to $88.46 \%$ with highest share coming from Bangladesh (88.46\%), followed by Australia (73.74\%), Canada (72.22\%), Singapore (70.0\%), U.K. (61.54\%), France (48.94\%), USA (48.25\%), Germany (46.97\%), Malaysia (44.27\%) and India (24.56\%) during 19992018.

\section{Subject-Wise Distribution of Research Output}

According to the Scopus classification, the global Nipah virus research output published during 1999-2018 is distributed across seven sub-fields, with medicine accounting for the highest publications share (50.97\%), followed by immunology and microbiology (42.51\%), biochemistry, genetics and molecular biology (21.25\%), agricultural and biological sciences $(11.85 \%)$, and other 3 sub-fields contribution varying from $4.57 \%$ to $6.10 \%$ during $1999-2018$. Its activity index, which computes change in research activity in the discipline over time 1999-2008 to 2009-18 (world average activity index of a given subject is taken as 100), witnessed increase in immunology and microbiology (from 86.30 to 108.68), biochemistry, genetics and molecular biology (from 61.64 to 124.30), agricultural and biological sciences (from 64.47 to 122.51), pharmacology, toxicology and pharmaceutics (from 59.86 to 125.43) and neurosciences (from 85.95 to 108.90), as against decline of research activity in medicine (from 103.23 to 97.95 ) and veterinary science (from 111.02 to 93.02 ) from 1999-2008 to 2009-18. Agricultural and biological sciences, among various subjects registered the highest citations impact per paper of 31.16 CPP, FOLLOWED BY immunology and microbiology (29.99), medicine (27.46), neurosciences (26.0) biochemistry, genetics and molecular biology (22.26), veterinary science (21.47) and pharmacology, toxicology and pharmaceutics (13.59) during 1999-2018 (Table 3).

\begin{tabular}{|c|c|c|c|c|c|c|c|c|c|c|c|c|c|}
\hline \multirow[t]{2}{*}{ S.No } & \multirow[t]{2}{*}{ Name of the Country } & \multicolumn{3}{|c|}{ Number of Papers } & \multicolumn{3}{|c|}{ Share of Papers } & \multirow[t]{2}{*}{ TC } & \multirow[t]{2}{*}{ CPP } & $\mathrm{HI}$ & ICP & \multirow[t]{2}{*}{$\% I C P$} & \multirow[t]{2}{*}{$\mathrm{RCl}$} \\
\hline & & $\begin{array}{l}1999- \\
2008\end{array}$ & $\begin{array}{c}2009- \\
18\end{array}$ & $\begin{array}{l}1999- \\
2018\end{array}$ & $\begin{array}{l}1999- \\
2008\end{array}$ & $\begin{array}{c}2009- \\
18\end{array}$ & $\begin{array}{l}1999- \\
2018\end{array}$ & & & \multicolumn{2}{|c|}{ 1999-2018 } & & \\
\hline 1 & USA & 186 & 357 & 543 & 40.61 & 49.38 & 45.98 & 20872 & 38.44 & 75 & 262 & 48.25 & 1.37 \\
\hline 2 & Australia & 82 & 116 & 198 & 17.90 & 16.04 & 16.77 & 8150 & 41.16 & 52 & 146 & 73.74 & 1.47 \\
\hline 3 & Malaysia & 75 & 56 & 131 & 16.38 & 7.75 & 11.09 & 6119 & 46.71 & 38 & 58 & 44.27 & 1.67 \\
\hline 4 & France & 22 & 72 & 94 & 4.80 & 9.96 & 7.96 & 2867 & 30.50 & 29 & 46 & 48.94 & 1.09 \\
\hline 5 & U.K. & 35 & 56 & 91 & 7.64 & 7.75 & 7.71 & 3263 & 35.86 & 28 & 56 & 61.54 & 1.28 \\
\hline 6 & Germany & 21 & 45 & 66 & 4.59 & 6.22 & 5.59 & 1714 & 25.97 & 20 & 31 & 46.97 & 0.93 \\
\hline 7 & India & 14 & 43 & 57 & 3.06 & 5.95 & 4.83 & 893 & 15.67 & 14 & 14 & 24.56 & 0.56 \\
\hline 8 & Canada & 17 & 37 & 54 & 3.71 & 5.12 & 4.57 & 1903 & 35.24 & 24 & 39 & 72.22 & 1.26 \\
\hline 9 & Bangladesh & 10 & 42 & 52 & 2.18 & 5.81 & 4.40 & 2054 & 39.50 & 21 & 46 & 88.46 & 1.41 \\
\hline \multirow[t]{4}{*}{10} & Singapore & 15 & 35 & 50 & 3.28 & 4.84 & 4.23 & 1384 & 27.68 & 17 & 35 & 70.00 & 0.99 \\
\hline & Total & 477 & 859 & 1336 & 104.15 & 118.81 & 113.12 & 49219 & 36.84 & 31.8 & 733 & & 1.31 \\
\hline & World & 458 & 723 & 1181 & & & & 33127 & 28.05 & & & & \\
\hline & $\begin{array}{c}\text { Share of } 10 \text { Countries in } \\
\text { World Total }\end{array}$ & 104.15 & 118.81 & 113.12 & 40.61 & 49.38 & 45.98 & 20872 & 38.44 & 75 & 262 & 48.25 & 1.37 \\
\hline
\end{tabular}




\begin{tabular}{|c|c|c|c|c|c|c|c|c|c|}
\hline \multirow[t]{2}{*}{ S. No } & \multirow[t]{2}{*}{ Subject* } & \multicolumn{3}{|c|}{ Number of Papers (TP) } & \multicolumn{2}{|c|}{ Activity Index } & \multirow[t]{2}{*}{ TC } & \multirow{2}{*}{$\begin{array}{c}\text { CPP } \\
1999-2018\end{array}$} & \multirow[t]{2}{*}{$\% \mathrm{TP}$} \\
\hline & & 1999-2008 & 2009-18 & $1999-2018$ & $1999-2008$ & 2009-18 & & & \\
\hline 1 & Medicine & 241 & 361 & 602 & 103.23 & 97.95 & 16533 & 27.46 & 50.97 \\
\hline 2 & $\begin{array}{l}\text { Immunology and } \\
\text { Microbiology }\end{array}$ & 168 & 334 & 502 & 86.30 & 108.68 & 15057 & 29.99 & 42.51 \\
\hline 3 & $\begin{array}{l}\text { Biochemistry, } \\
\text { Genetics and } \\
\text { Molecular Biology }\end{array}$ & 60 & 191 & 251 & 61.64 & 124.30 & 5588 & 22.26 & 21.25 \\
\hline 4 & $\begin{array}{c}\text { Agricultural and } \\
\text { Biological Sciences }\end{array}$ & 35 & 105 & 140 & 64.47 & 122.51 & 4363 & 31.16 & 11.85 \\
\hline 5 & Veterinary Science & 31 & 41 & 72 & 111.02 & 93.02 & 1546 & 21.47 & 6.10 \\
\hline 6 & $\begin{array}{l}\text { Pharmacology, } \\
\text { Toxicology and } \\
\text { Pharmaceutics }\end{array}$ & 13 & 43 & 56 & 59.86 & 125.43 & 761 & 13.59 & 4.74 \\
\hline \multirow[t]{2}{*}{7} & Neurosciences & 18 & 36 & 54 & 85.95 & 108.90 & 1404 & 26.00 & 4.57 \\
\hline & World Output & 458 & 723 & 1181 & & & & & \\
\hline
\end{tabular}

- There is overlapping of literature covered under various subjects

TP=Total Papers; TC=Total Citations; $\mathrm{CPP}=$ Citations Per Paper

\section{Profile of Top 15 Most Productive Global Organizations}

Three hundred fifty four (354) organizations participated in global research on Nipah Virus during 1999-2018, of which 298 organizations contributed 1-10 papers each, 31 organizations 11-20 papers each, 18 organizations 21-50 papers each, 5 organizations 51-100 papers each and 2 organizations 101-118 papers each. The productivity of top 15 most productive global organizations in Nipah Virus research varied from 28 to 118 publications and together they contributed $65.11 \%$ (769) publication share and 99.15\% (32844) citation share during 1999-2018. The scientometric profile of these top 15 organizations is presented in Table 4.

- Five of these organizations registered publications output greater than the group average of 51.27: CSIRO, Animal Health Laboratory, Geelong, Victoria, Australia (118 papers), Centre for Disease Control and Prevention, Atlanta, USA (113 papers), University of Malaya, Malaysia (73 papers), Uniformed Services University of Health Science, Bethesda, USA (65 papers) and National Institute of Health, Bethesda, USA (56 papers) during 1999-2018;

- Seven organizations registered citation impact above the group average of 42.71 citations per publication during 2008-17: University of Malaya, Malaysia (56.04), Centre for Disease Control and Prevention, Atlanta, USA (52.30), Queensland Department of Agriculture and Fisheries, Brisbane, Australia (47.77), CSIRO, Animal Health Laboratory, Geelong, Victoria, Australia (47.43), National Institute of Health, Bethesda, USA (46.50), Uniformed Services University of Health Science, Bethesda, USA (43.31) and Mount Sinai School of Medicine, New York, USA (43.03) during 1999-2018;

- Six organizations contributed international collaborative publications share above the group average of 56.91\%: International Centre for Diarrheal Disease Bangladesh (97.44\%), EcoHealth Alliance, New York, USA (85.71\%), Queensland Department of Agriculture and Fisheries, Brisbane, Australia (80.65\%), CSIRO, Animal Health Laboratory, Geelong, Victoria, Australia (78.81\%), Centre for Disease Control and Prevention, Atlanta, USA (69.91\%) and Uniformed Services University of Health Science, Bethesda, USA (69.23\%) during 1999-2018
- Seven organizations registered the relative citation index above the group average (1.52) of all organizations: University of Malaya, Malaysia (2.0), Centre for Disease Control and Prevention, Atlanta, USA (1.86), Queensland Department of Agriculture and Fisheries, Brisbane, Australia(1.70), CSIRO, Animal Health Laboratory, Geelong, Victoria, Australia (1.69), National Institute of Health, Bethesda, USA (1.66), Uniformed Services University of Health Science, Bethesda, USA (1.54) and Mount Sinai School of Medicine, New York, USA (1.53) during 1999-2018

\section{Profile of Top 15 Most Productive Authors}

Five Hundred Fifty six (556) authors participated in global research on Nipah Virus um during 1999-2018, of which 494 authors contributed 1-10 papers each, 2 authors' 63-84 papers each. The research productivity in the field of Nipah Virus research of top 15 most productive authors varied from 27 to 84 publications. Together they contributed $48.69 \%$ (575) global publication share and 89.29\% (29579) citation share during 1999-2018. The Scientometric profile of these 15 authors is presented in Table 5.

- Four authors registered publications output above the group average of 38.33: L.F. Wang (84 papers), C.C. Broader (63 papers), B. Lee (43 papers), P. Daszak (41 papers) during 1999-2018;

- $\quad$ Five authors registered impact above the group average of 51.44 citations per publication: K.B. Chua (123.56), T.G. Ksiazek (1101.42), P.E. Rollin (74.14), P.A. Rota(65.22) and G. Crameri (63.60) during 1999-2018

- Eight authors contributed international collaborative publications share above the group average of $70.43 \%$ of all authors: E.S. Gurley (97.22\%), S.P. Luby (92.11\%), G. Crameri (90.0\%), L.F. Wang (85,71\%), H.E. Field (81.82\%), T.G.Ksiazek (80.56\%), P. Daszak (78.05\%), P.E. Rollin (71.43\%) during 1999-2018;

- $\quad$ Five authors registered the relative citation index above the group average (1.83) of all authors: K.B. Chua (4.40), T.G. Ksiazek (3.62), P.E. Rollin (2.64), P.A. Rota (2.33) and G. Crameri (2.27) during 1999-2018. 


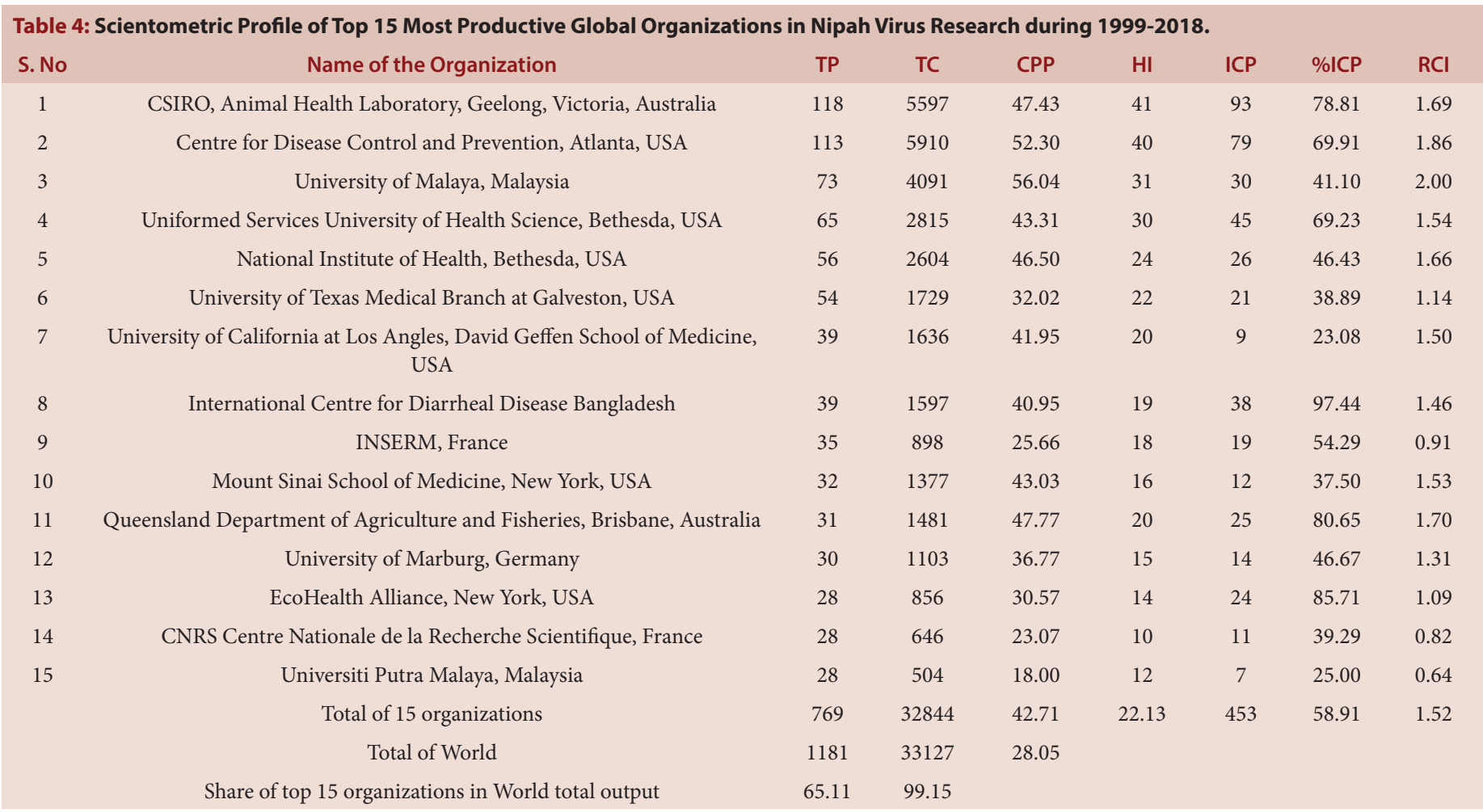

TP=Total Papers; TC=Total Citations; CPP=Citations Per Paper; HI=h-index; ICP=International Collaborative Papers; RCI=Relative Citation Index

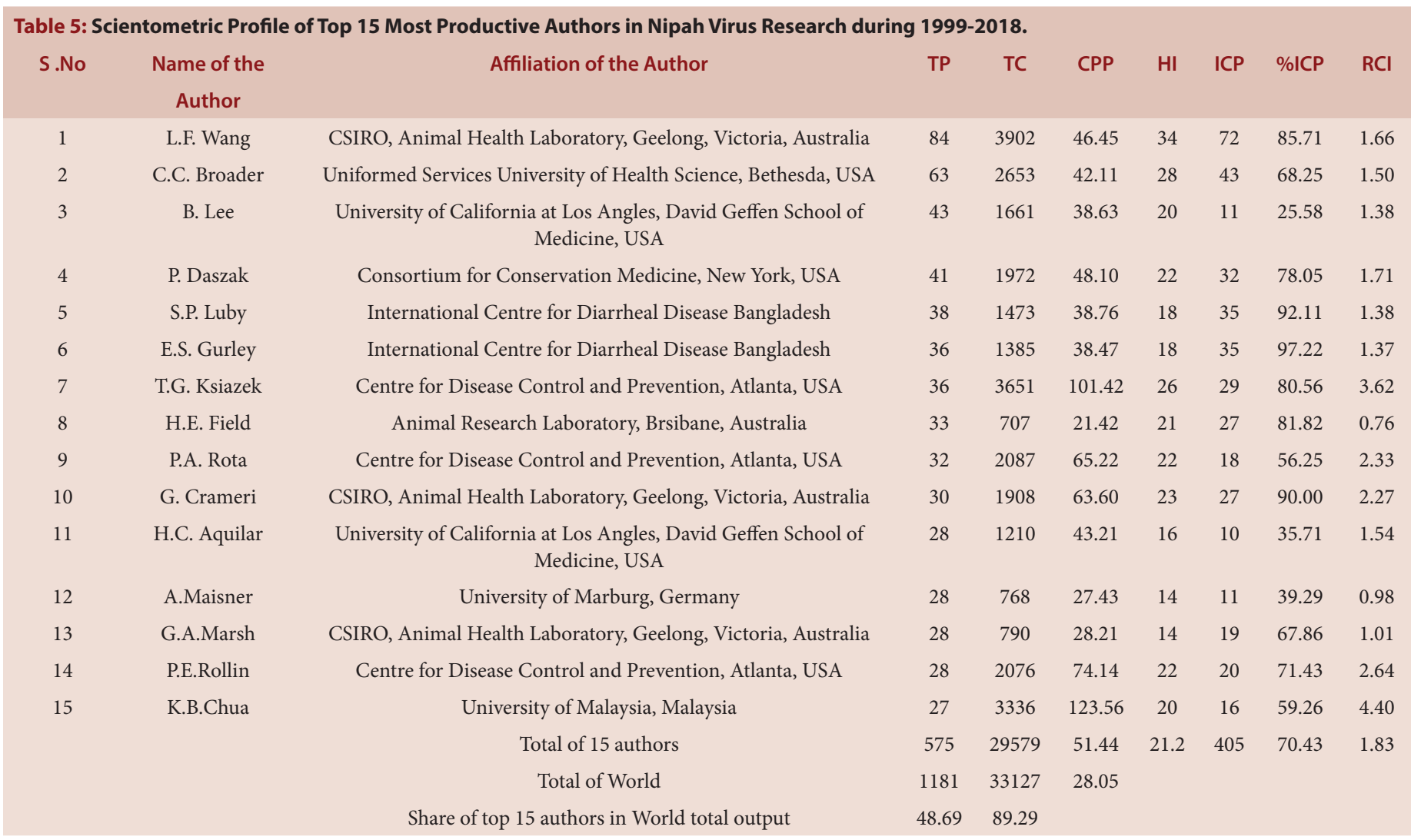

TP=Total Papers; TC=Total Citations; CPP=Citations Per Paper; HI=h-index; ICP=International Collaborative Papers; RCI=Relative Citation Index 


\section{Medium of Research Communication}

Of the total world output on Nipah Virus research, 91.19\% (1077) appeared in journals, $4.40 \%$ (50) in books, $3.81 \%$ (45) in book series and $0.59 \%$ (7) in conference proceedings publications during 1999-2018. 1077 journal papers appeared in 410 journals, of which 380 journals published 1-5 papers each, 13 journals 6-10 papers each, 14 journals 11-30 papers each, 2 journals 31-50 papers each and 1 journal 103 papers during 1999-2018. The top 20 most productive journals reported 9 to 33 papers each on Nipah Virus research; together they accounted for $40.39 \%$ (435 papers) of total Nipah Virus output published in journals during 1999-2018, shown increase from $35.27 \%$ to $43.81 \%$ share between 1999-2008 and 2009-18. The top ranking journal is Journal of Virology (with 103 papers), followed by Emerging Infectious Diseases (44 papers), PLOS One (37 papers), Journal of General Virology (25 papers), PLOS Pathogens (22 papers each), etc. during 1999-2018 (Table 6).

\section{Significant Keywords}

Around 40 significant keywords have been identified from the literature which through light on the research trends in Nipah Virus research. These keywords are listed in Table 7 in the decreasing order of the frequency of their occurrence in the literature during 1999-2018.

\section{Highly Cited Papers}

A total of 79 highly cited papers were identified in the nipah virus literature, each having 101 to 793 citations (56 papers each in citation range 101-200, 18 papers each in citation range 201-400, 3 papers in citation range 401-500 and 2 paper in citation range 667-793) in 20 years during 19992018. Together these 79 papers cumulated a total of 14880 citations, averaging 188.35 citations per paper. Of the 79 highly cited papers, 21 resulted from the participation of research organizations in their role as stand-alone (non-collaborating) institutional authors and remaining 58 from two or more research organizations working in their role as collaborating partners per paper (17 national collaborative and 41 international collaborative). Among 79 highly cited papers, the largest participation was seen from USA ( 52 papers), followed by the Australia (22 papers), Malaysia (17 papers), France ( 9 papers), U.K. (8 papers), Bangladesh (7 papers), Canada, Germany and Singapore (4 papers each), Ghana (3 papers)< Cambodia, Canada, China, Denmark, Hong Kong, Madagasagar, Panama, South Africa, Sweden and Switzerland (2 papers each) and 14 other countries including India (1 paper each). These 79 highly cited papers involved the participation of 721 personal authors and 298 research organizations in total across globe. The leading organizations participating in high cited papers were: Centre for Disease Control and Prevention, Atlanta, USA (18 papers), CSIRO, Animal Health Laboratory, Geelong, Victoria, Australia (17 papers), University of Malaya (10 papers), Uniformed Services University of Health Science, Bethesda, USA (7 papers), University of California at Los Angles, David Geffen School of Medicine, USA and International Centre for Diarrheal Disease Bangladesh (6 papers each), National Institute of Health, Bethesda, USA and Mount Sinai School of Medicine, New York, USA (5 papers each), University of Texas Medical Branch at Galveston, USA and Queensland Department of Agriculture and Fisheries, Brisbane, Australia (4 papers each), University of Marburg, Germany and EcoHealth Alliance, New York, USA (3 papers each), etc. The leading authors participating in high cited papers were: T.G. Ksiazek (13 papers), L. F. Wang (12 papers), K.B. Chua (10 papers), C.C. Broader, P.A. Rota, G. Crameri and P.E. Rollin (7 papers each), B. Lee (6 papers), S.P. Luby, E.S. Gurley and H.C. Aquilar (5 papers each), etc.

Of the 79 highly cited papers, 62 were published as article, 15 as review papers and 2 as conference papers. These 79 highly cited papers were published in 39 journals, with 13 papers in Journal of Virology, 11 papers

\begin{tabular}{|c|c|c|c|c|}
\hline \multirow[t]{2}{*}{ S. No } & \multirow[t]{2}{*}{ Name of the Journal } & \multicolumn{3}{|c|}{ Number of Papers } \\
\hline & & $\begin{array}{l}1999- \\
20080\end{array}$ & $\begin{array}{c}2009- \\
18\end{array}$ & $\begin{array}{l}1999- \\
2018\end{array}$ \\
\hline 1 & Journal of Virology & 33 & 70 & 103 \\
\hline 2 & Emerging Infectious Diseases & 22 & 22 & 44 \\
\hline 3 & PLOS One & 2 & 35 & 37 \\
\hline 4 & Journal of General Virology & 8 & 17 & 25 \\
\hline 5 & PLOS Pathogens & 2 & 20 & 22 \\
\hline 6 & Virology & 11 & 10 & 21 \\
\hline 7 & Journal of Virological Methods & 9 & 10 & 19 \\
\hline 8 & Virology Journal & 7 & 11 & 18 \\
\hline 9 & Science & 11 & 5 & 16 \\
\hline 10 & Virus Research & 6 & 10 & 16 \\
\hline 11 & Current Opinion in Virology & 0 & 13 & 13 \\
\hline 12 & Neurology Asia & 2 & 11 & 13 \\
\hline 13 & Vaccine & 2 & 11 & 13 \\
\hline 14 & Antiviral Research & 2 & 10 & 12 \\
\hline 15 & Future Virology & 2 & 10 & 12 \\
\hline 16 & Journal of Infectious Diseases & 8 & 3 & 11 \\
\hline 17 & OIE Revue Scientifique Et Technique & 7 & 4 & 11 \\
\hline 18 & Archives of Virology & 5 & 5 & 10 \\
\hline 19 & Proceeding of NAS of USA & 4 & 6 & 10 \\
\hline \multirow[t]{4}{*}{20} & Microbes and Infection & 9 & 0 & 9 \\
\hline & Total of 20 journals & 152 & 283 & 435 \\
\hline & Total global journal output & 431 & 646 & 1077 \\
\hline & $\begin{array}{c}\text { Share of top } 20 \text { journals in global } \\
\text { journal output }\end{array}$ & 35.27 & 43.81 & 40.39 \\
\hline
\end{tabular}

in Emerging Infectious Diseases, 5 papers in Microbes and Infection, 3 papers in PLOS One, PLOS Pathogens, Proceeding of the NAS of USA and Science, 2 papers each in American Journal of Pathology, Annals of Neurology, Clinical Infectious Diseases, Journal of Comparative Pathology, Lancer, Nature and OIE Revue Scientifique Et Technique and 1 paper each in 26 other journals.

\section{CONCLUSION AND SUMMARY}

Research publications (1181 publications) on Nipah virus during the last 20 years (1999-2018) were derived from the Scopus database with a view to study it's quantitative and qualitative bibliometric characteristics. The publication data showed that the annual output increased from 7 in 1999 to 106 in 2013 and the decreased to 57 in 2017, registering $16.23 \%$ annual growth. Its cumulative publication output in ten-years (19992008) increased from 458 to 723 publications during succeeding ten-year period $2009-18$, registering $57.86 \%$ growth. Nipah virus global citation impact averaged to 28.05 citations per paper in 10 years, which decreased from 46.83 to 16.15 from $2008-12$ to $2013-17$.

Although global research output in the field of Nipah Virus research had originated from 62 countries, however, more than $100 \%$ of its global research output and citation share was from just top 10 most productive countries. The top 10 most productive countries global share individually varied widely $4.23 \%$ to $45.98 \%$ during $1999-2018$, with USA accounting for the highest publication share (45.98\%), followed by Australia (16.77\%), 


\begin{tabular}{|c|c|c|c|c|c|}
\hline S. No & Keyword & Frequency & S. No & Keyword & Frequency \\
\hline 1 & Nipah Virus & 930 & 21 & SARS Coronavirus & 84 \\
\hline 2 & Hendra Virus & 360 & 22 & Viral Encephalitis & 79 \\
\hline 3 & Paramyxoviridae & 346 & 23 & Cercopithecus Aethiops & 75 \\
\hline 4 & Hanipavirus Infection & 302 & 24 & Measles Virus & 75 \\
\hline 5 & Virus Infection & 250 & 25 & West Nile Flavivirus & 70 \\
\hline 6 & Paramyxovirus & 234 & 26 & Viruses & 69 \\
\hline 7 & Virology & 229 & 27 & Virus Vaccine & 63 \\
\hline 8 & Virus Transmission & 204 & 28 & HIV Virus & 58 \\
\hline 9 & Bat & 202 & 29 & Rabies Virus & 57 \\
\hline 10 & Zoonosis & 194 & 30 & Swine Diseases & 55 \\
\hline 11 & Chiroptera & 163 & 31 & Influenza Virus & 49 \\
\hline 12 & Virus Encephalitis & 146 & 32 & Coronavirus & 48 \\
\hline 13 & Swine & 142 & 33 & Hantavirus & 58 \\
\hline 14 & Genetics & 120 & 34 & Horse & 48 \\
\hline 15 & Encephalitis & 113 & 35 & Escherichia Coli & 47 \\
\hline 16 & Viral Antibodies & 96 & 36 & Japanese Encephalitis Virus & 46 \\
\hline 17 & Virus Protein & 94 & 37 & Antiviral Activity & 45 \\
\hline 18 & Severe Acute Respiratory Syndrome & 91 & 38 & West Nile Virus & 44 \\
\hline 19 & Emerging Communicable Diseases & 86 & 39 & RNA Viruses & 47 \\
\hline 20 & Ebola Virus & 85 & 40 & Dengue & 40 \\
\hline
\end{tabular}

Malaysia (11.09\% share) and other 7 countries (from $4.23 \%$ to $7.96 \%$ ) during 1999-2018. The global publication share of these top 10 countries showed increase in USA, France, Bangladesh, India, Germany, Singapore, Canada and U.K. (from $0.10 \%$ to $8.77 \%$ ), as against decrease in Malaysia and Australia (from $1.86 \%$ to $8.63 \%$ ) in ten years period (1999-2008 and 2009-18). Four of top 10 countries scored relative citation index above the world average of 1.28: Malaysia (1.67), Australia (1.47), Bangladesh (1.41) and USA (1.37) during 1999-2018. The international collaborative papers share of top 10 most productive countries in Nipah virus research varied widely from $24.56 \%$ (India) to $88.46 \%$ (Bangladesh). The other top 8 countries international collaborative publication share varied from $44.27 \%$ to $73.74 \%$ during $1999-2018$.

Medicine was the most sought after subject area of Nipah virus research, accounting for $(59.97 \%)$ the highest publications share, followed by immunology and microbiology (42.51\%), biochemistry, genetics and molecular biology (21.25\%), agricultural and biological sciences (11.85\%), and other 3 sub-fields contribution varying from $4.57 \%$ to $6.10 \%$ during 1999-2018. Among broad subjects, the research activities registered increase immunology and microbiology, biochemistry, genetics and molecular biology, agricultural and biological sciences, pharmacology, toxicology and pharmaceutics and neurosciences, as against decline of research activity in medicine and veterinary science from 1999-2008 to 2009-18. Agricultural and biological sciences, among various subjects, registered the highest citations impact per paper of 31.16 CPP, followed by immunology and microbiology (29.99), medicine (27.46), neurosciences (26.0) biochemistry, genetics and molecular biology (22.26), veterinary science (21.47) and pharmacology, toxicology and pharmaceutics (13.59) during 1999-2018

354 organizations and 556 authors participated in global research on Nipah Virus during 1999-2018, of which the top 15 most productive research organizations and the authors collectively contributed $65.11 \%$ and $48.69 \%$ global publication share and $99.15 \%$ and $89.29 \%$ global citation share respectively during 2008-17. The leading organizations in terms of publication productivity were: CSIRO, Animal Health Laboratory, Geelong, Victoria, Australia (118 papers), Centre for Disease Control and Prevention, Atlanta, USA (113 papers), University of Malaya, Malaysia (73 papers), Uniformed Services University of Health Science, Bethesda, USA (65 papers) and National Institute of Health, Bethesda, USA (56 papers) during 1999-2018. The leading organizations in terms of citation impact per paper were: University of Malaya, Malaysia (56.04), Centre for Disease Control and Prevention, Atlanta, USA (52.30), Queensland Department of Agriculture and Fisheries, Brisbane, Australia (47.77), CSIRO, Animal Health Laboratory, Geelong, Victoria, Australia (47.43), National Institute of Health, Bethesda, USA (46.50), Uniformed Services University of Health Science, Bethesda, USA (43.31) and Mount Sinai School of Medicine, New York, USA during 1999-2018. The leading authors in terms of publication productivity were: L.F. Wang (84 papers), C.C. Broader (63 papers), B. Lee (43 papers), P. Daszak (41 papers) during 1999-2018. The leading authors in terms of citation impact per paper were: K.B. Chua (123.56), T.G. Ksiazek (1101.42), P.E. Rollin (74.14), P.A. Rota (65.22) and G. Crameri (63.60) during 1999-2018.

The journals medium (1077 articles published in 410 journals) ) accounted for $91.19 \%$ global publications share in Nipah virus research with top 20 most productive journals accounting for $40.39 \%$ of total publications output in journals during 1999-2018. Journal of Virology contributed the largest number of papers (103 papers), followed Emerging Infectious Diseases (44 papers), PLOS One (37 papers), Journal of General Virology (25 papers), PLOS Pathogens (22 papers each), etc. during 1999-2018

Of the total Nipah virus global research output, 79 publications registered high citations, in the range of 101-793 citations per paper and collectively these highly cited papers received a total of 114880 citations, 
averaging to 188.35 citations per paper. These 79 highly cited papers involved the participation of 721 personal authors and 298 research organizations and were published in 39 journals, with 13 papers in Journal of Virology, 11 papers in Emerging Infectious Diseases, 5 papers in Microbes and Infection, 3 papers in PLOS One, PLOS Pathogens, Proceeding of the NAS of USA and Science, 2 papers each in American Journal of Pathology, Annals of Neurology, Clinical Infectious Diseases, Journal of Comparative Pathology, Lancer, Nature and OIE Revue Scientifique Et Technique and 1 paper each in 26 other journals

WHO in collaboration and consultation with leading national and international experts and organizations and other key stakeholders is developing a Nipah Research and Development (RandD) Roadmap. The main purpose of this roadmap is to provide a framework for identifying the vision, underpinning strategic goals, and prioritizing areas and activities (from basic research to advanced development, licensure, manufacture and deployment) for accelerating the collaborative development of medical countermeasures (MCMs) - diagnostics, therapeutics, and vaccines-against Nipah virus infection. The RandD roadmap for $\mathrm{NiV}$ infection is a key component of the WHO RandD Blueprint initiative for accelerating research and product development of medical countermeasures to enable effective and timely emergency response to infectious disease epidemics. NiV is identified in the Blueprint's list of "priority pathogens" (defined as pathogens that are likely to cause severe outbreaks in the near future and for which few or no MCMs exist). Other aspects of public health preparedness and response, in addition to RandD for MCMs, are critical to successful NiV infection prevention and control. Examples include enhanced surveillance systems, minimizing zoonotic NiV transmission, improved personal protective equipment (PPE), effective community engagement, adequate infection prevention and control practices, and workforce development and training in endemic and at-risk regions. Many of these issues are beyond the scope of the RandD roadmap, but need to be addressed as part of a broader public health control strategy.

\section{REFERENCES}

1. Pierre RE. Nipah Virus Disease. In. Emerging Infectious Diseases. Clinical Case Studies. 2014:175-84. https://doi.org/10.1016/B978-0-12-416975-3.00013-3

2. Decoding the deadly Nipah virus by Preeti Zachariah. 2018. http://www.thehindu. com/sci-tech/health/decoding-the-deadly-nipah-virus/ article24011196.ece (Accessed on 30 May 2018)

3. Denis M. NIPAH Baseline Situation Analysis. 2018. http://www.who.int/ blueprint/priority-diseases/key-action/WHO_NIPAH_baseline_situation_analysis_ 27Jan2018.pdf? ua=1 (Accessed on 30 May 2018)

4. WHO. Nipah virus-Key Facts. 2018. http://www.who.int/news-room/fact-sheets/ detail/nipah-virus (Accessed on 30 May 2018)

5. Centers for Disease Control and Prevention (CDS). Nipah Virus (NiV). 2014. https://www.cdc.gov/vhf/nipah/index.html (Accessed on 30 May 2018)

6. Safahieh H, Sanni SA, Zainab AN. International Contribution to Nipah Virus Research 1999-2010. Malaysian Journal of Library and Information. 2012;17(3):35-47.

Cite this article : Gupta BM, Ahmed KKM, Gupta R. Nipah Virus Research: A Scientometric Assessment of Global Publications Output during 1999-2018. Int J Med Public Health. 2018;8(2):48-55. 